\title{
Significant Ways to Improve the Performance of Medium and Large Local Contractors in the Jigawa State, Nigeria
}

\author{
Rozlin Zainal $^{1}$, Garba Hamza ${ }^{2}$, Norpadzlihatun Manap ${ }^{1}$, and Noor Shahifah Syahrom ${ }^{1}$ \\ ${ }^{1}$ Department of Construction Management, Faculty of Technology Management and Business, Universiti Tun \\ Hussein Onn Malaysia, 86400 Parit Raja, Batu Pahat, Johor, Malaysia \\ ${ }^{2}$ Ministry of Education Science and Technology, Dutse, Jigawa State, Nigeria
}

\begin{abstract}
Contractors' performance is an important criterion for the success of any construction project, as it is the contractor that converts designs into practical reality. While evidence suggests that there is much need for further improvement particularly in cost, time and quality, in Nigeria contractors' performance is the subject that requires much research. This paper is to identify the significant ways to improve the performance of medium and large local contractors in the Jigawa state, Nigeria. Literature about contractors and their performance was reviewed to identify the ways believed to improve their performance in executing construction projects. Questionnaires distributed to 45 clients, 45 consultants, and 45 medium and large local contractors. The findings show that the respondents agree that the most significant ways to improve medium and large local contractor's performance are transparent bidding process mechanism, proper selection of construction procurement system, quality control and standard assurance, local contractor patronage by the government and adopting information and communication technology (ICT) in design and construction. This paper offers better performance and expands the pool of knowledge to the Nigerian contractor regarding essential element that is needed to be observed in order to improve their performance.
\end{abstract}

\section{Introduction}

Construction industry plays a significant role in the economy of developing countries. In many developing countries, main construction activities account for about $80 \%$ of the total capital assets, 10 $\%$ of their Gross Domestic Product (GDP), and more than $50 \%$ of the wealth invested in fixed assets. Also, the industry provides high employment opportunity, probably next after agriculture [1]. Similarly, Nigeria with a population of over 179 million people and Africa's largest economy as at 2014 after its Gross Domestic Product (GDP) was rebased in 2013 to stand at N82.2 trillion (US\$510 billion). Its construction industry provides three (3\%) percent of the nation's (GDP) Gross Domestic Product [2].

In developing countries, problems associated with contractor's performance are higher and even compounded as a result of inadequate resources and organizations to address them [3-8]. In Nigeria, the construction industry is vibrant and the largest in Africa but also been challenged to improve its performance [9-10]. As a result of multiple complications in the Nigerian construction industry, which in-built in the construction projects, it is clear that the construction industry is project based and it is mainly dealing with various interests of multiple stakeholders that results to various changes. These changes seriously affect the productivity aspects of the contractor's performance
[10-11]. Local contractors' performance is a critical issue to the success of any construction project, as it is a contractor who converts designs into practical reality. While the local contractor performance has been the subject of much research, evidence suggests that there is much need for further improvement [12]. A number of numerous studies conducted have shown that Nigerian local contractor's performance in construction projects execution was inferior. [13] reported that Nigerian contractors come to the limelight with the introduction of the Nigeria Enterprises Promotion decree of February 1972, and since then local contractors have been playing an essential role in the construction industry. Until recently their performance becomes deficient that cannot be considered for the award of major notable construction projects in Nigeria. [14-15] have shown that the Nigerian local contractors suffer from many problems and complex issues. Consequently, it faced with the significant problems of high cost of project delivery, bad financial performance and unable to deliver value to customers on time. As a result, local contractors have been criticized extensively for poor performance and inefficient productivity [10-11].

Successful construction companies used performance measurements to ensure meeting their objectives. Source of waste determined through this measurement in order for that company to focus its effort. It is time to provide a timely and accurate

* Corresponding author: padzliha@,uthm.edu.my 
response to the competence and efficiency of operations and to focus attention on continuous development $[16,17,28]$.

Local contractors' performance is measured and evaluated using a large number of performance indicators that might be related to the predominant performance evaluation measurements scopes of cost, time and quality [17]. Performance measurement becomes more important to the contractors it improved and sustained their business in the long-term. Most large construction organisations practice performance measurement because they believe it gives an optimistic impact to their businesses in the long-term. Performance measurement is seen as an important way of keeping an organisation on track in achieving the organisation's objectives and strategy [18].

[19] mentioned that usually, local contractor's performance measurements influenced by identifying efficiency and effectiveness, undertaking a critical evaluation of all features of management such as leadership, planning, renewable, non-renewable resources, financial and workforces, which will assist the managerial staff to formulate effective strategies that help towards achieving the aims and objectives. [20] stated that local contractors' performance measurement is related to time, budget, quality, specifications and stakeholder's satisfaction. It is an improvement of cost, schedule, and quality for design and construction stages.

Poor performance of local (medium and large) contractors in the industry are predominantly related to problems and performance let-down by many factors as such; problems of shortages or inadequacies in industry infrastructure (mainly supply of resources), problems caused by clients (additional work at the clients request, changes in design and time taken in payment from client to the contractor) and consultants and problems caused by contractor incompetence and inadequacies are performance problems in the construction industry that causes failure $[34,35,36]$.

[21] identified that the local contractor's performance problem is related to poor budgetary and time control, problems arise in large construction projects due to many restrictions in personnel competence and overall construction project management. [22] stated that the main performance problem of local contractors are unrealistic planning that the construction process may deviate from what planned initially. Scopes of local contractor's performance identified as; effectiveness, efficiency, quality, productivity, quality of work, innovation and profitability. Research on the performance of local contractors in building and civil engineering projects in many countries believed that the performance of local contractors influenced by external and internal factors. Design-bid-build is cost control techniques; it relies on manual data collection which means that it is done at low frequency and quite sometime after the controlled event occurred. Moreover, human error in data collection usually resulted in poor quality data [20]. Similarly, traditional performance measurement systems have cost efficiency-based measures derived from a strategy to minimized production cost, described as a cost leadership strategy.

Apart from internal risks arising within the construction project itself, according to [23], the local contractor's performance is affected by many factors including politic, economic, social and cultural risks [19,24,25]. Clients usually measure the performance of local contractors using cost, time and quality [26]. Besides, it concluded that the form of building procurement client's experience, the form of the building, project organizational structure and labour force are existing factors to project time performance [27]. Past researchers have identified the factors influencing local contractor performance include cultural, economic, political, social, physical, aesthetic, financial, legal, institutional, technological and policy [24,27].

According to [4], there is a need to focus on the effort made by economist, contractors and the construction industry associations to provide the infrastructure needed for efficient project management and performance [28]. Based on the above, it shows that there are factors accountable for medium and large local contractors' poor performance. As such, this paper is aiming to formulate ways to improve the performance of medium and large local contractors' in the Jigawa state Nigerian construction industry. This, in turn, will offer better performance and also will expand the pool of knowledge to the Nigerian contractor regarding essential element that is needed to be observed in order to improve their performance.

\section{Methodology}

Findings from literature reviewed $[9,33,12,10,11,14,15]$ form the bases for drafting the questionnaire. The questionnaire was sent out for a pilot test to ensure that the questions provide required data undoubtedly.

A structured questionnaire sent to the target respondents which lead formulate ways to improve the performance of medium and large local contractors in Jigawa state Nigerian construction industry. The survey conducted in which 11 factors were identified and ranked from a client, consultants, and medium and large local contractor's perspectives. One hundred thirty-five questionnaires distributed as follows: 45 to clients, 
45 to consultants, 45 to medium and large contractors each. One hundred nineteen questionnaires were received $(88.1 \%)$ from respondents as follows: $(85.7 \%)$ from clients, $(80 \%)$ from consultants and $(90 \%)$ from local contractors. The respondents were experienced client, consultants, and local (medium and large) contractors. Eleven factors believed to improve medium and large local contractors' performance were considered in this study based on the literature reviewed.

\section{Result and Discussion}

Results indicate that the most significant ways to improve the medium and large local contractors' performance in the Jigawa state Nigerian construction industry according to the respondents' perception are transparent bidding process mechanism which has a mean of 4.31 and ranked one (1) in the ways to improve the performance of local contractors. The successful execution of a construction project is heavily impacted by making the right decision during tendering processes; a transparent bidding process improves the performance of the local contractor in the Nigerian construction industry. This result is in line with the work of Mohemad et al., (2010); [32,15,29] despite the difference in period and location. With the transparent bidding process issue of corruption will be drastically minimized or wipe out completely.

The second way to improve the performance of local contractors in the Nigerian construction industry as indicated by the respondents is proper selection of construction procurement system which is ranked two (2) by the respondents and is having a mean of 4.29. This result is in agreement with the work of [29]. Proper selection of construction procurement system will solve the problems of additional work given during construction and used of the unskilled labour force.

Furthermore, quality control and standard assurance indicated ways to improve the performance of local contractors as the third (3) in the ranking based on the respondents' responses and is having the mean of 4.18 . This is an initiative to solve quality problems. Another way to improve the performance of local contractors in the Nigerian construction industry as indicated by respondents is local contractor's patronage by the government which has a mean of 4.18 and is ranked fourth (4) in the mean ranking. As in the case of Nigeria where the government is the primary client in the construction industry, among the challenges facing local contractors, are lack of government patronage, this is in agreement with the work of [9-11] despite these research respondents are medium and large contractors moreover, time and location difference.
Therefore, by patronizing local contractors will solve problems of project cash flow, the time taken in payment from the client to the contractor and will improve the performance of local contractors in the Nigerian construction industry.

The fifth way to improve the performance of local contractors in the Nigerian construction industry as indicated by the respondents is adopting information and communication technology (ICT) in design and construction. It had a mean of 4.13 and ranked fifth (5) in the ranking table. [9,31] agreed that despite these research respondents are medium and large contractors moreover, time and location difference. Use of ICT in construction will assists in planning, organizing, coordinating and controlling. It will also improve project sustainable development dimensions. Moreover, 0.824 obtained as Cronbach's Alpha of reliability test conducted on the Ways to improve the performance of medium and large local contractors in Jigawa state Nigerian construction industry factors.

\section{Conclusion and recommendations}

This research aims to formulate significant ways to improve the performance of local contractors in the Nigerian construction industry. The questionnaire was sent to various potential respondents to disclose their opinions on the ways to improve the performance of medium and large local contractors in the Jigawa state Nigerian construction industry. Based on the respondents disclosed opinions, significant ways identified from the survey conducted, these are transparent bidding process mechanism, proper selection of construction procurement system, quality control and standard assurance, local contractor patronage by the government and adopting information and communication technology (ICT) in design and construction. These five (5) most significant factors were confirmed based on their mean values. The identified ways will promote local contractor performance in the Nigerian construction industry as they are vital not only in the industry but in national development.

The authors recommended that Government should come up with an effective mechanism to ensure transparent bidding process, to overcome the issue of delay and cost problems. Furthermore, renewable and non-renewable resources should be developing in the Nigerian construction industry, through quality training and meetings in order to update knowledge and assist with project management processes and techniques, for construction projects performance. Clients are recommended to facilitate payment to contractors to overcome delay, disputes, and claims. Stakeholders in the construction industry must 
ensure efforts to achieve the required level of quality for a product which is well planned and organized. Maintaining the quality of construction works at the required standard will obtain customers' satisfaction, this, in turn, would bring long-term competitiveness and business survival for the industries.

Contractors should consider risk assessment in their cost estimation in order to adhere to project specifications in order to overcome delay, disputes, and performance problems of time and cost. Moreover, Contractors should also adhere to the use of quality materials to improve cost, time, and quality performance and should avoid taking too many projects that cannot execute successfully.

This research was performed to fulfil the requirements of a research grant (Vote no. R063). Acknowledgments are given to the Ministry of Higher Education Malaysia and the Office for Research, Innovation, Commercialization and Consultancy Management, Universiti Tun Hussein Onn Malaysia for their support during the publication of this paper

\section{References}

1. A. H. Yimam, University of Maryland College Park, (2011)

2. I. T., Terwase, A. N. Abdul-Talib and K. T. Zengeni, Nigeria, International Business Perspective, (2014)

3. S. Gushibet, Journal of Economics, Volume 4, Issue I, (2012)

4. N. Manap, N.H. Mohd Noh and N. Syahrom, IOP Conference Series: Earth and Environmental Science, 109, 012011.2017.

5. N. Manap, Y.K. Goh and N. Syahrom, IOP Conference Series: Earth and Environmental Science, 109, 012008.2017.

6. N. Manap, K.Y. Tan and N. Shahrom, IOP Conference Series: Earth and Environmental Science, 109, 012026.2017.

7. N. Manap and N. Voulvoulis, Applied Mechanics and Materials, 567, pp. 50-55 .2014 .

8. N. Manap, N.I. Muhamad and K. Sandirasegaran, Materials Science Forum, $\mathbf{8 8 9}$ 261-264.2017.

9. I. I. Inuwa, G. Wanyona and S. Diang'a, African Journal of Applied Research, Volume 1, Issue (1), 2015.

10. S. J. Odediran, Journal of Architecture, Planning and Construction Management, Volume 2, Issue 2, 2012

11. S.J. Odediran, B.F., O.A. Adeyinka Opatunji, and K.0. Morakinyo, International Journal of Business Research and Management, Volume 3, Issue 5, pp. 255-264, 2012.
12. L.M. Amusan, Covenant University, OgunState, Nigeria, (2012)

13. G.I. Idoro, Journal of Construction in Developing Countries, Volume 17, Issue 1(1), pp. 1-19, 2012.

14. O. Oladimeji and G. K. Ojo, 4th Processions of West Africa Built Environment Research (2012)

15. K. Bala, A. Bello B. A. Kolo, and S, A. Bustani Procs 25th ARCOM Conference, 7-9 Sept. 2009, pp. 351-359, Nottingham U.K.: ARCOM, 2009.

16. D.Amaratunga, D. Baldry and M. Sarshar, Work Study, Volume 50, Issue 5, pp. 179-88, 2001.

17. S. Ahmad, Doctoral dissertation, San Diego State University, (2014)

18. B., Xiong, M. Skitmore, B. Xia, M.A.N. Masrom, K. Ye, and A. Bridge, International Journal of Project Management, Volume 32, Issue 3, pp. 482-491, 2014.

19. A. A. Latiffi, P. M. Carrillo, K. Ruikar, \& C. J. Anumba, (2010)

20. P. Muchiri, L. Pintelon, L. Gelders, and H. Martin, International Journal of Production Economics, Volume 131, Issue 1, pp. 295302, 2011.

21. R. B. Isa, R. A. Jimoh and E. AchuenuNet Journal of Business Management, Volume 1, Issue 1, pp. 1-6, 2013.

22. I.O. Famakin, I. O., Aje and D.R. Ogunsemi, Journal of Financial Management of Property and Construction, Volume 17, Issue 2, pp. 153-165, 2012.

23. S. Y. Kim and T. A. Huynh, International Journal of Project Management, Volume 26, Issue 7, pp. 758-769, (2008)

24. Z. Hatush and M. Skitmore, Volume 15, Issue 1, pp. 19-38, (1997)

25. S.O.Ojo, Civil Engineering Dimension, Volume 11, Issue 2, pp. 106, (2009)

26. M.O.Dada and B. U. Akpadiaha, International Journal of Architecture, Engineering and Construction, Volume 1, Issue 2, pp. 103-111, 2012.

27. A.A. Aliyu, H. Adamu, A. A. Abdul, and I. M. Singhry, Journal of Energy Technologies and Policy, Volume 5, Issue 8, pp. 11-22, (2015)

28. N. Manap, N. Jeyaramah, and N. Syahrom, IOP Conference Series: Earth and Environmental Science, 109, 012027 (2017)

29. M. Sohail, S. Cavill, Journal of Construction Engineering and Management. Volume 134, Issue 9, pp. 729-738, 2008.

30. S. Isaac and R. Navon, Automation in Construction, Volume 31, pp. 31-40, (2013) 
31. S. Okunlola Ojo, O. Aina, and A. Yakeen, Journal of Civil Engineering and management, Volume 17, Issue 2, pp. 227-233, (2011)

32. C.Kenny, Transport Reviews: A Transnational Transdisciplinary Journal. Volume 29, Issue 1, pp. 21-41, (2009)

33. B. Mafimidiwo and R. Iyagba, Journal of Emerging Trends in Economics and Management Sciences, Volume 6, Issue 2, (2015)

34. N. Manap, R.A.A., Raja Bedali, K. Sandirasegaran, M.A.N. Masrom, and M.Y.
Yahya, Jurnal Teknologi, 78(3), pp. 87-92 (2016)

35. K. Sandirasegaran and N. Manap, Jurnal Teknologi, 73(3): 139-143.(2016)

36. N. Manap, S. Polis, K. Sandirasegaran, M.A.N. Masrom, K.C. Goh, and M.Y. Yahya, Jurnal Teknologi, 78(3), pp. 111-116 (2016) 